\title{
Application of the Microbubble Enhanced Ozonolysis Technology in Biomass Utilisation
}

\author{
Dmitriy Kuvshinov, Anggun Siswanto, Jagroop Pandhal, William Zimmerman
}

\begin{abstract}
One of the major fields of Bioscience Engineering application is biomass production and utilisation. Increasing the rate of the biomass production has raised the need for the development of the new efficient low cost techniques for the bio-waste management. Nowadays this became an emerging issue not only for a municipal environment but also for the rural conditions.
\end{abstract}

Jatropha cake (JC) is a waste biomass from the biofuel industry which uses an equatorial crop Jatropha curcas Linn as the raw material. The production of $\mathrm{JC}$ is significant with no economical profit. Due to its natural toxicity, the high nutritious $\mathrm{JC}$ is utilised as a combustion material (fuel).

Thermal, chemical and biological methods have been tested as means of the JC detoxification. However, the toxic component, phorbol ester (PE), is known for its stability at high temperatures up to $160{ }^{\circ} \mathrm{C}$. At that level the heat treatment can have a negative effect on the nutritious content of JC. Utilisation of solvents to reduce $P E$ content requires additional steps for the solvent regeneration in which leads to the increase of production cost. The long time factor of the detoxification process is seen as the main drawback of the biological approach in reducing $P E$.

Dmitriy Kuvshinov

School of Engineering, University of Hull, Hull HU6 7RX

United Kingdom

Anggun Siswanto

Department of Chemical and Biological Engineering, The University of Sheffield, Sheffield S1 3JD

United Kingdom

Jagroop Pandhal

Department of Chemical and Biological Engineering, The University of Sheffield, Sheffield S1 3JD

United Kingdom

William Zimmerman

Department of Chemical and Biological Engineering, The University of Sheffield, Sheffield S1 3JD

United Kingdom
In this paper the experimental data on the development of the new JC detoxification approach with application of micro bubbles enhanced ozonolysis technique is presented. Issues concerning efficiency of the ozone application for the PE detoxification in the Ghanaian Jatropha cake and ozone driven protein degradation are discussed. It was shown that at optimized operating conditions the protein content in the detoxified $\mathrm{JC}$ was reduced by $30 \%$ of its original level and the treated waste JC could be used as a fish and cattle feed.

Keywords - bioscience engineering, jatropha cake, microbubble, ozone, protein.

\section{Introduction}

Development of the oil rich waste biomass conversion technologies able to supply food or/and fuel to meet changing market requirements is essential for the economy of equatorial belt countries, where the oil rich crops are widely cultivated.

Jatropha curcas Linn is one of the key crops [1] in the biofuel sectors. This plant has an ability to grow in the tropical regions on the low quality soil. It is expected that by 2015 the Jatropha plantations of 12.8 million hectares producing up to 4.1 tons of seed/ha (around 2 tons of oils/ha) will be developed worldwide [2].

Jatropha cake (JC) is a by-product of biofuel industry. $\mathrm{JC}$ is produced at the seed de-fatting step. It is reported that $270 \mathrm{~kg}$ of JC was obtained by processing of 1T Jatropha seeds [3]. This ratio gives significant amount of JC with a high residual amino acids content equal to the protein guideline for children [4]. With a high level of crude protein around $53 \%-58 \%$ Jatropha can be utilized as an alternative food, feed stock or fertilizer [5].

Currently the only use of JC is a combustion material. The high content of a natural carcinogenic compound called phorbol ester (PE) is the reason for this limited JC utilisation [6]. The PE stays in both the oil and the JC [7-9].

The problem of PE detoxification has been previously addressed with an application of the heat treatment [10]. Unfortunately this method cannot be applied as it results in a very low remaining protein content in JC. Chemical 
methods with alcohols application are expensive and relatively complicated.

Development of Bioscience Engineering fields includes application of modified and adapted chemical/materials engineering technologies to the bio-active materials' treatment. Low temperature plasma produced by the corona discharge, dielectric barrier discharge reactors [11] is widely applied in industry. One of the main applications of the plasma reactors on an industrial scale is the ozone generation. Ozonolysis is recognized as a clean technology as no by-products are produced. The non reacted ozone molecules will dissociate back into oxygen. Ozone application (ozonolysis) fields include waste water treatment [12], aquaculture, food processing and effluent treatment [13].

In order to improve ozonolysis as a multiphase process modern microbubble technology is introduced. Microbubbles stay longer in the bulk of liquid therefore the contact time between the gas and the liquid is increased. Smaller bubble size enhances the transfer rate in the interfacial surface area, resulting in higher process effectiveness [14].

In this research, we propose a combination of plasma microreactor and the microbubble technology as a novel approach for the bio waste JC treatment with the emphasis given to the evaluation of the protein content during ozonolysis. The $\mathrm{C}=\mathrm{C}$ bonds in the $\mathrm{PE}$ molecular structure are expected to be destroyed by the ozone resulted to chemical structures with a lower or even zero toxicity. Therefore the technology under development targets JC detoxification and its conversion to a food source.

\section{Materials and Methods}

\section{A. Jatropha cake treatment}

Ozonolysis of ground Ghanaian jatropha cake has been done with the experimental set up, settings and procedures described earlier [15]. The ozonolysis was carried out for 5 hours with samples being taken every hour. The treated samples were dried and used further for the protein quantification.

\section{в. Ozone concentration measurement}

The ozone concentrations in liquid and gas phases were measured by using the Indigo method [16]. The absorbance of the decolourised indigo was measured at wavelength of $600 \mathrm{~nm}$ with the use of DR 2800 Hach-Lange spectrophotometer. Calibration curve was done prior to the experimentation.

\section{Protein quantification}

Tests were done on the raw and treated samples by extracting the protein in two different solvents: water and the triethylammonium bicarbonate (TEAB) buffer purchased from Sigma Aldrich. In order to extract the protein, a sample was mixed with a solvent followed by centrifugation with Eppendorf 5424 Centrifuge, for 20 minutes (rotation $=2100 \mathrm{cfg}$ ). The resulting supernatant was analyzed for the protein quantification by using the Bradford assay. Triplicate experimentations were carried out. Absorbance was measured at $595 \mathrm{~nm}$ using a spectrophotometer, Ultrospec 2100 pro Amersham Biosciences.

\section{Morphology investigation}

The morphology of JC was investigated by Scanning Electron Microscopy with use of JSM-6010LA Analytical SEM JEOL microscope.

\section{Results and Discussion}

Advantages of the DBD plasma reactor downscaling has been numerically proven with an application of COMSOL Multiphysics software $[15,17]$. It was shown that in order to keep the optimal level of electrical field constant, the external applied voltage must be decreased as the dimensions of the system are reduced. The low voltage applied is a key factor for an effective reduction of plasma temperature [17]. These conditions contribute to cutting down the operating cost since the ozone generation is more effective at low temperatures.

The plasma unit developed was tested for the ozone production. Samples of $1.5 \mathrm{~L}$ distilled water were treated for 2 minutes with a plasma reactor powered at $4 \mathrm{kV}$ and various air flow rates. The data is presented in table 1.

TABLE 1. PROFILE OF OZONE CONCENTRATION IN VARIOUS FLOW RATES

\begin{tabular}{|l|l|l|}
\hline \multirow{2}{*}{ Flow rate (L/min) } & \multicolumn{2}{|l|}{ Ozone concentration (ppm) } \\
\cline { 2 - 3 } & Dissolved Ozone & Gas phase Ozone \\
\hline 1 & 19.89 & 0 \\
\hline 2 & 26.53 & 0 \\
\hline 3 & 25.85 & 0 \\
\hline
\end{tabular}

It was found that the level of the dissolved ozone strongly depends on the air flow rate. At $1 \mathrm{~L} / \mathrm{min}$ the lowest observed ozone concentration can be explained by oxygen limited formation of ozone. Highest ozone concentration in a liquid phase was obtained at $2 \mathrm{~L} / \mathrm{min}$ flow rate. This case has an optimal ratio of the fresh gas volume entering the plasma region to the electric field of the ignited plasma. Lower dissolved ozone concentration at $3 \mathrm{~L} / \mathrm{min}$ flow rate could be described by a non reacted air injection to the liquid which affects the gas-liquid ozone diffusion process.

It is important to note that the ozone was not detected in the gas phase for tested conditions. This is the evidence that the ozone produced by the developed plasma unit at selected conditions was mainly accumulated in water. Therefore no gas outflow post treatment is needed. 
Proc. of the Fourth Intl. Conf. Advances in Bio-Informatics, Bio-Technology and Environmental Engineering- ABBE 2016

Copyright (C) Institute of Research Engineers and Doctors, USA .All rights reserved.

ISBN: 978-1-63248-091-0 doi: 10.15224/ 978-1-63248-091-0-04

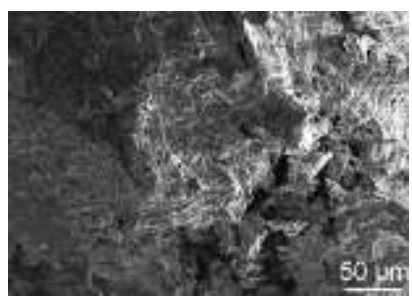

(a)

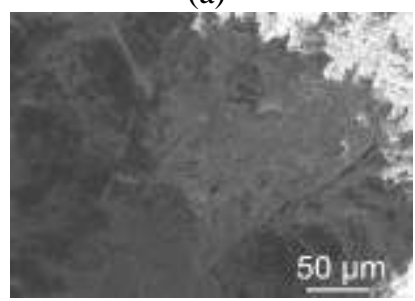

(c)

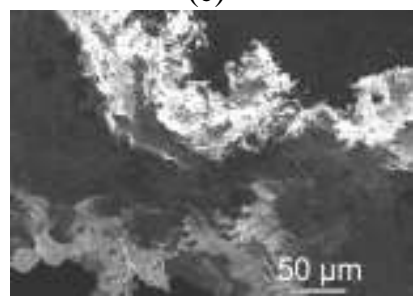

(e)

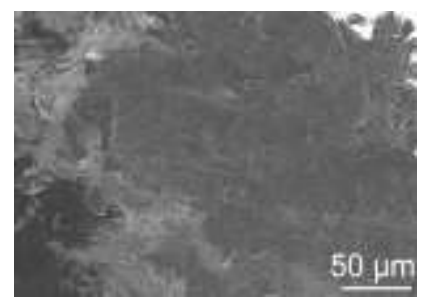

(b)

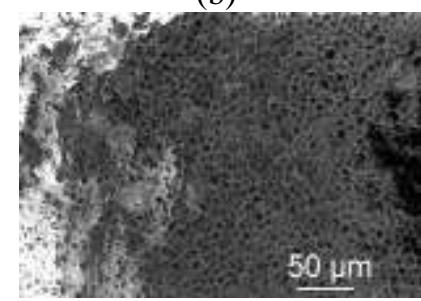

(d)

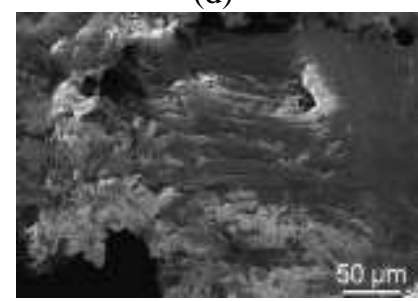

(f)
Figure 1. Morphology of JC during ozonolysis, (a) before ozonolysis; (b)1 hour of ozonolysis; (c) 2 hours of ozonolysis; (d) 3 hours of ozonolysis; (e) 4 hours of ozonolysis; (f) 5 hours of ozonolysis.

Ozone effect on JC microstructure has been investigated with a SEM, Fig 1. In comparison with the raw material for a sample after one hour of ozonolysis there doesn't appear to be a significant change in structure, Fig. 1 (a \& b). Two hours of processing resulted in a porous structure with a formation of holes, Fig. 1 (c). After three hour of treatment the structure had a significant difference to original one. Low density and foam like materials have been formed due to the ozone etching, Fig. 1 (d). Morphology of the JC was gradually degraded with a further treatment with porous structures formation.

In order to analyse the effect of the ozone on the nutritious level, protein content in $\mathrm{JC}$ was quantified before, during and after the ozonolysis (Fig.2). The Bradford assay was selected due to its sensibility for a wide range of protein content.

Fig. 2 presents experimental data on the effect of ozonolysis to protein content of JC. Protein content is presented for the case of two solvents application. Difference observed in the detection with application of buffer and water is due to ability of specially designed TEAB to extract protein more effectively from supernatant.

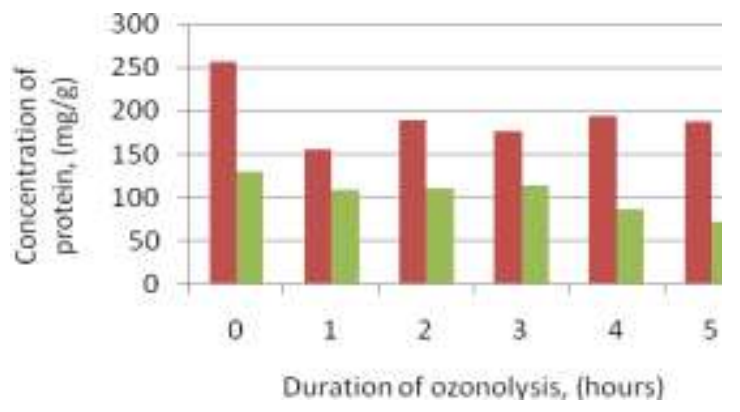

Fig 2. Ozonolysis effect on protein content of Jatropha Cake (red: sample in buffer, green: sample in water)

Taking into account the SEM data, the substantial reduction of the protein content after the first hour of ozonolysis, Fig. 1, can be described by an enhanced access of ozone to the cells' content as the majority of the surface layer cells were broken out at the pressing step and at the grinding stage during the preparation of samples. Ozone is constantly consumed by the degradation of cells. Therefore after the first drop in the concentration, from the second hour of the process, the protein extracted from the newly ozone opened cells was less affected by the decreased concentration of water dissolved ozone. This resulted in a higher protein content detected. This simultaneous process, cell membrane degradation by ozone and protein extraction from one side and protein content degradation by ozone oxidation from another, continues to govern the level of the protein observed. This explains the rather stable protein content observed after 5 hours of ozonolysis.

It has been previously reported that at the similar conditions synthetic Phorbol ester was completely broken down within 10 minutes of ozonolysis [18]. Therefore the optimal processing time seems to be less than one hour. This gives a protein concentration in the treated $\mathrm{JC}$ of $150 \mathrm{mg} / \mathrm{g}$ which is above the protein content in the fish feed [19].

\section{Conclusions}

It was found that the application of the efficient plasma reactions delivering advanced ozonolysis by microbubble dispersion has shown promising detoxification kinetics and energetic for Jatropha curcas Linn. Non toxic meals have a high residual protein content and can be used as a cattle or fish feed stock. The data obtained has a direct application for development and adaptation of modern plasma technologies in the waste biomass management and the food sector. 
Proc. of the Fourth Intl. Conf. Advances in Bio-Informatics, Bio-Technology and Environmental Engineering- ABBE 2016

Copyright $\odot$ Institute of Research Engineers and Doctors, USA .All rights reserved.

ISBN: 978-1-63248-091-0 doi: 10.15224/ 978-1-63248-091-0-04

\section{Acknowledgements}

We gratefully acknowledge the UK Wellcome Trust and EPSRC (EP/K001329/1) through the 4CU (4cu.org.uk) Programme Grant for support.

AS would also to acknowledge The Directorate General of Higher Education Indonesia and the Education Attaché, the Embassy of the Republic of Indonesia in United Kingdom for doctoral scholarship.

\section{References}

[1] Devappa, R.K., H.P.S. Makkar, and K. Becker, Jatropha Diterpenes: a Review. Journal of the American Oil Chemists Society, 2011. 88(3): p. 301-322.

[2] Devappa, R.K., H.P.S. Makkar, and K. Becker, Nutritional, Biochemical, and Pharmaceutical Potential of Proteins and Peptides from Jatropha: Review. Journal of Agricultural and Food Chemistry, 2010. 58(11): p. 6543-6555.

[3] Makkar, H.P.S. and K. Becker, Jatropha curcas, a promising crop for the generation of biodiesel and value-added coproducts. European Journal of Lipid Science and Technology, 2009. 111(8): p. 773-787.

[4] Makkar, H.P.S., G. Francis, and K. Becker, Protein concentrate from Jatropha curcas screw-pressed seed cake and toxic and antinutritional factors in protein concentrate. Journal of the Science of Food and Agriculture, 2008. 88(9): p. 1542-1548.

[5] Annongu, A.A., et al., Detoxification of Jatropha curcas seeds for Use in nutrition of monogastric livestock as alternative feedstuff. Pakistan Journal of Nutrition, 2010. 9(9): p. 902-904.

[6] Heller, J., Physic nut. Jatropha curcas L. Promoting the conservation and use of underutilized and neglected crops. Institute of Plant Genetics and Crop Plant Research, Gatersleben/ International Plant Genetic Resources Institute, Rome., 1996.

[7] Wink, M., et al., Phorbol Esters of J. curcas - Biological Activities and Potential Applications, in Biofuels and Industrial Products from J.Curcas, Gubitz, Mittelbach, and M. Trabi, Editors. 1997. p. 160166.
[8] Zucker, M.B., Troll, W., and Belma, S., The tumor promoter phorbol ester (12-0-tetradecanoyl-phorbol-13-acetate), a potent aggregating agents for blood platelets. The Journal of Cell Biology, 1974. 60: p. 325-336.

[9] Aderibigbe, A.O., et al., Chemical composition and effect of heat on organic matter-and nitrogen-degradability and some antinutritional components of Jatropha meal. Animal Feed Science and Technology, 1997. 67(2-3): p. 223-243.

[10] Kumar, A. and S. Sharma, An evaluation of multipurpose oil seed crop for industrial uses (Jatropha curcas L.): A review. Industrial Crops and Products, 2008. 28(1): p. 1-10.

[11] Nehra, V., A. Kumar, and H.K. Dwivedi, Atmospheric non-thermal plasma source. International Journal of Engineering, 2008. 2(1).

[12] Agency, U.E.P., Wastewater Technology Fact Sheet Ozone Disinfection, O.o. Water, Editor. 1999, EPA 832-F-99-063: Washington, D.C.

[13] Barlow, P., J, An Introduction to Ozone Generation, in Technical Director. 1994, Watertec Engineering Pty Ltd.

[14] Zimmerman, W.B., Tesar, V., Butler, S., Bandulusen, H.C.H, Microbubble generation. Recents Patents on Engineering, 2008. 2(1): p. 1-8.

[15] Kuvshinov, D., et al., Efficient Compact Micro DBD Plasma Reactor for Ozone Generation for Industrial Application in Liquid and Gas Phase Systems. International Journal of Chemical, Materials Science and Engineering, 2014. 8(1): p. 82-85.

[16] Bader, H. and J. Hoigné, Determination of ozone in water by the indigo method. Water Research, 1981. 15(4): p. 449-456.

[17] Lozano-Parada, J.H., Zimmerman, W.B, The role of kinetics in the design of plasma microreactors. Chemical Engineering Science, 2010. 65(17): p. 4925-4930.

[18] Kuvshinov, D., A. Siswanto, and W.B. Zimmerman, Microbubbles Enhanced Synthetic Phorbol Ester Degradation by Ozonolysis. International Journal of Chemical, Materials Science and Engineering, 2014. 8(1): p. 78-81.

[19] Kumar, V., H.P.S. Makkar, and K. Becker, Detoxified Jatropha curcas kernel meal as a dietary protein source: growth performance, nutrient utilization and digestive enzymes in common carp (Cyprinus carpio L.) fingerlings. Aquaculture Nutrition, 2011. 17(3): p. 313-326. 